\title{
Sustaining extended enterprises as a matter of institutional logics: insights from the railway sector
}

\author{
Maria Lammerdina Bobbink, Andreas Hartmann and Geert Dewulf \\ Department of Construction Management and Engineering, University of Twente, Enschede, The Netherlands
}

\begin{abstract}
Purpose - This paper aims to investigate the effect of institutional logics on the intended resource coordination and integration in extended enterprises (EEs).

Design/methodology/approach - The qualitative multiple case study approach collected data from three EEs and their hierarchical organizational context in the restructured and privatized railway sector of the Netherlands by observing 40 meetings, conducting 31 semi-structured interviews and 9 feedback meetings and perusing organizational documents.

Findings - Performance and professional logics characterized the EEs and their hierarchical organizational context. Aligning these logics failed to support the resource coordination and integration in the EEs because of the logics' resource-centric nature. The co-creation logic in one of the EEs mitigated this resource centrism by addressing the resource personifications and representations of the professional and performance logics. Business unit representatives having hierarchically overlapping organizational positions supported this change process by offering protection from resource-centric logics.

Research limitations/implications - The chosen research design limits the generalization of the findings but reveals new scientific and practical insights on the role of institutional logics for sustaining EEs.

Practical implications - The various EE business-units, but especially their contract and concession authorities, need to realize the crippling effect of resource-centric logics on sustaining an EE. Becoming aware of the resource personifications and representations of these logics can assist in addressing their negative effects.

Originality/value - No previous studies have empirically investigated the effect of institutional logics on the intended resource coordination and integration in EEs.
\end{abstract}

Keywords Integration, Coordination, SCM performance, Public-private extended enterprises, Institutional logics, Resource integration, Railways

Paper type Research paper

\section{Introduction}

Since the 1980s, private and public organizations have been privatizing and outsourcing the non-core operational activities of and resources for their product services to reduce costs and risks. To maximize the value of their product-services, they spread the responsibility for delivering these services over various organizations through contracts and/or concessions (Bititci et al., 2012; Osborne et al., 2013). The organizations, in turn, delegate this responsibility to their operational business units that now have to coordinate and re-integrate activities into an interoperable supply chain process. What emerges are hierarchically bound heterarchical, i.e. level-playing, supply chain clusters that do not possess the management authority derived from labor contracts and call for new inter-organizational resource coordination and integration mechanisms. The notion of the extended enterprise (EE) has been introduced as one of these supply chain clusters (Gulati et al., 2012).

An EE is a supply chain cluster that, led by a focal unit, coordinates and integrates the various resources of its units, and thus maximizes the value of its overall product-service delivery and optimizes the same for each of its units (Post et al., 2002; Bititci

The current issue and full text archive of this journal is available on Emerald Insight at: https://www.emerald.com/insight/1359-8546.htm

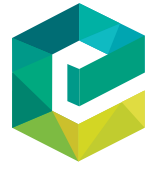

Supply Chain Management: An International Journal 26/1 (2021) 136-150

(C) Emerald Publishing Limited [ISSN 1359-8546] [DOI 10.1108/SCM-12-2019-0457] et al., 2005). In support of this, scholars have suggested interrelated performance measurement systems to integrate financial and organizational information (Bititci et al., 2005; Folan and Browne, 2005; Verdecho et al., 2012) and the building of a shared identity to facilitate information sharing, open contractual borders and level power differences (Paulin and Ferguson, 2010; Braziotis and Tannock, 2011). Finally, scholars proposed fitting organizational designs in support of the aforementioned suggestions (O'Neill and Sackett, 1994; Barratt, 2004; Bobbink et al., 2016).

Despite the positive effect of supply chain integration on firms (Leuschner et al., 2013), coordinated resource-integrating supply chains and EEs are rare (Fawcett and Magnan, 2002; Masten and Kim, 2015; Spekman and Davis, 2016). First, this is due to the continued predominance of firm-centric business models and performance management and measurement approaches that are based on the tenet of contract authority (Gulati et al., 2012). Second, firm owners and contractually responsible managers and employees structure and arrange their processes and related work routines in support of their own product service. As a result, they have little or no experience with inter-organizational resource coordination and integration (Barratt, 2004; Arshinder and Deshmukh, 2008; Fawcett et al., 2015). Third, organizations and/

This research is part of the Explorail Research Program funded by NWO (the Dutch Research Council), ProRail (the Dutch Railway Agency) and Technology Foundation STW (a NWO division).

Received 20 December 2019

Revised 27 June 2020

21 August 2020

Accepted 25 August 2020 
or business units misuse and try to sustain their power-position (Kähkönen, 2014). Finally, this is because of barriers leading to mistrust, such as the non-existence of an EE identity and perceptions of incongruous risk and benefit-sharing (Spekman and Davis, 2016). One by one, these reasons point at different assumptions, values and beliefs that the involved individual and organizational actors use in their interaction and that are grounded in their negotiated, experienced and reproduced resourcecoordinating and integrating actions (Friedland and Alford, 1991; Thornton et al., 2012; Edvardsson et al., 2014). These so-called institutional logics provide organizational principles and blueprints to individuals, organizations and societies, which when sinking in, eventually become the "taken for granted aspects of human behavior" (Cloutier and Langley, 2013, p. 360). This paper puts forward the argument that these institutional logics support and hamper the resource coordination and integration in supply chains and, thus, represent main drivers or barriers for the emergence of EEs. As the effect of institutional logics on establishing and sustaining EEs has received little attention, this paper aims to answer the following research question:

RQ1. How do the institutional logics affect the intended resource coordination and integration in EEs?

To answer this question it used a qualitative multiple case study method involving three EE settings rooted in the vertically restructured and privatized railway sector of The Netherlands. The chosen research design enabled to discern three institutional logics: the performance, professional and cocreation logic. The prevalent performance and professional logic led to resource segregation among EE-partners; the coexisting co-creation logic softened this effect and facilitated resource coordination and integration. These findings contribute to the wider debate on the coordination and integration challenges in supply chain management in general (Bititci et al., 2012; Osborne et al., 2013; Stevens and Johnson, 2016) and supply chain clusters such as EEs in particular (Lehtinen and Ahola, 2010; Spekman and Davis, 2016) by giving insights into the nested context of institutional logics and their role in establishing collaborative supply chains.

Section 2 elaborates on the theoretical concepts used, i.e. the extended enterprise and institutional logics, followed by a Section 3 on the research method. Subsequently, the paper presents the research findings in Section 4. Finally, it discusses these findings and shares conclusions and recommendations for future studies in Sections 5 and 6.

\section{Conceptual background}

\subsection{Extended enterprises and their resource coordination and integration}

The number of firms involved in supply chains has increased over time. Simultaneously, the need for resource coordination and integration in supply chains has increased too. This includes the task of initiating and sustaining activity planning and performance improvements (Wang et al., 2018) and the process of reducing identity and power differences, inventory and lead times (Cox, 1999; Power, 2005). In support of both, supply chains have usually copied the contract-authority based hierarchical firm design resulting in high coordination costs, reduced performances and environmental and social excesses (Flynn et al., 2010; Stevens and Johnson, 2016). Meanwhile, addressing these coordination and integration challenges through advanced information technologies, strategies, tools, techniques and the incorporation of social and environment concerns appear to rather mask than cope with them (Goldstein and Newell, 2019; Seepma et al., 2020).

Devolving supply chains into EEs, though, comes with the promise of business units engaging in "[...] collective and mutually supportive [activities], such that any conflict can be addressed." Stevens and Johnson (2016, p. 32) and in doing so maximize their collective service, optimize each business unit's service and contribute to maximizing the product-service of their hierarchical supply chain (Bititci et al., 2005; Bobbink et al., 2016). However, none of these business units possesses the contractbased authority to settle conflicts (Gulati et al., 2012). This calls for a, mutually accepted, focal business unit coordinating the integration of an EE-units' resources (O'Neill and Sackett, 1994; Post et al., 2002), and the mandate and agency of the business units to integrate these resources that are often socially differently valued (Scott, 2012, p. 31) whether they are natural, technical, intellectual, financial, legal, social and/or cultural (Table 1).

The reflection and action of an EE's business units on their resource coordination and integration can strengthen their agency and mutual norms in support of it and increase their EEenhancing practices (Lemke et al., 2011; Edvardsson et al., 2014). Hence, an EE's resource-coordinating and integrating practices, are not, but become (Power, 2005; Edvardsson et al., 2014).

However, recent studies have shown that EEs hardly reflect on the translation of their value-adding activities into EE-enhancing practices (Spekman and Davis, 2016). Sharing information about available resources appears to remain restricted to business units having a direct interface (Heather et al., 2015). The underlying reason for this dyadic integration might be that units embody and objectify similar resources leading to what can be called resource personification and representation (Bourdieu, 1986). Resource personification refers to resources internalized by actors and reflected in an actor's personality, thinking and acting (e.g. being a traffic manager) (Laud et al., 2015). Resource representation refers to resources reflected in human- and nature-made objects (e.g. timetables) (Ngoye et al., 2019). These eventually may sink in and turn into differing institutional logics, which may act as a barrier for resource integration, as is suggested by research on intra- (Pache, 2010) and inter-organizational change (Shaw et al., 2017).

Table 1 Resources and their definition adapted from Bourdieu (1986, 2005), Scott (2012), Gulati et al. (2012)

\begin{tabular}{ll}
\hline Definition of resources \\
\hline Natural & Not made by humans \\
Technical & All human-made objects \\
Intellectual & Human knowledge and skills \\
Financial & $\begin{array}{l}\text { Invested, saved and circulating money } \\
\text { Legal }\end{array}$ \\
Social & $\begin{array}{l}\text { Representations such as concessions and contracts } \\
\text { Relational networks, both personal and virtual, } \\
\text { based on shared identities and interpersonal ties }\end{array}$ \\
Cultural & $\begin{array}{l}\text { Actors positions and conditions based on inherited } \\
\text { and acquired properties, such as status, respect, } \\
\text { reputation }\end{array}$ \\
\end{tabular}




\subsection{Institutional logics}

Supply chain research frequently uses the concepts of coercive, normative and mimetic institutional pressures of DiMaggio and Powell's (1983) neo-institutional theory on isomorphism because its explains the uniformity and persistence in organizational structures, cultures and output (id., p.147) and with it the success or failure of intra- and inter-organizational practices and coordination (Kauppi, 2013; Wang et al., 2018; Gligor et al., 2019). The theory's origin is seldom referred to Kauppi and Hannibal (2017) because the institutional context that organizations have to cope with are usually considered as given (Ocasio and Gai, 2020).

Institutional pressures are derived from various societal institutional orders, i.e. "[...] multifaceted durable social structures made up of symbolic elements [i.e. rules, norms, common beliefs], social activities and material resources." (Scott, 2013, Ch. 3, p. 5), such as the state, religion or family. Another strand of institutional theory, organizational institutionalism (Ocasio and Gai, 2020) posits that they are underlain by institutional logics, i.e. "socially constructed, historical patterns of material practices, assumptions, values, beliefs and rules" (Thornton et al., 2012, p. 804) that result from and reinforce the cognition, behavior and resource use of societal, organizational and individual actors, thus providing the organizing principles for their distinct resource-coordinating and integrating practices (Thornton et al., 2012; Edvardsson et al., 2014; Besharov and Smith, 2014).

Friedland and Alford (1991) defined institutional logics by revealing the categorical elements of "[...] the most important institutional orders of contemporary Western societies[...]. Capitalism, family, bureaucratic state, democracy and Christianity [...] (pp. 248-249)." Thornton et al. (2012) refined and added to both the categorical elements and institutional orders using the analysis of existing studies and their own research. Based on nine, non-exhaustive, categorical elements, they distinguished the underlying logics of seven institutional orders, respectively, family, community, state, religion, market, profession and corporation (Thornton et al., 2012). The first column of Table 2 presents these categorical elements.
The categorical elements assist both the analysis of empirical research and the unveiling of the inter-institutional system to which actors are subject, for example, the institutional orders family, market and religion. Actors combine the elements of their inter-institutional system in addressing resource-coordinating and integrating situations and in doing so, they develop their own institutional logic. The majority of institutional logics therefore do not directly relate to one of the institutional orders at society level (Friedland and Alford, 1991; Thornton et al., 2012).

Whether an institutional logic changes and sustains depends on the agency of the actor(s) that bring it into being and incarnate it, and the number of actors that sustain it (Edvardsson et al., 2014). In this context, agency refers to "the ability to have some effect on the social world-altering the rules, relational ties or distribution of resources" (Scott, 2013, Ch. 4, p. 17).

Institutional logics, thus, emerge from and have an effect on actors' resource-coordinating and integrating actions, experiencing and collaboration (Smets et al., 2012; Besharov and Smith, 2014; Edvardsson et al., 2014). However, to our knowledge, no one has addressed this effect on the intended resource coordination and integration in EEs and their nested context. This paper, therefore, aims to address this gap by investigating the effect of institutional logics on three EEs in the railway sector of The Netherlands. The following section explains the design for this investigation.

\section{Research design}

\subsection{Research context}

In 2005, the National Railways in The Netherlands was privatized through national and provincial concessions. As then, the state is the authority of the national railway infrastructure concession and the train operation concession. The provincial governments possess the authority for the train operation concessions on the predominantly single-track railway tracks at the regional level. Hence, the national train service became the concessionary responsibility of several organizations.

Based on the planned construction activities, the concessionowning Railway Agency (RA) annually sets up a negotiation process among the remaining concession-owners to schedule the

Table 2 Categorical elements of institutional logics based on Thornton et al. (2012, p. 56)

\begin{tabular}{|c|c|}
\hline Categorical elements & Definition \\
\hline Root metaphor & $\begin{array}{l}\text { Basic structural form of experience that increases the understanding of what is common to a phenomenon by means of another } \\
\text { phenomenon, thus supporting the engagement of actors in understanding and organizing their world (Morgan, 1983) }\end{array}$ \\
\hline Sources of legitimacy & The underlying factors securing the social acceptability and credibility of actors (Scott, 2012) \\
\hline Sources of authority & The underlying factors securing the acceptance of orders by contributing actors (Barnard, 1968; Spencer, 1970; Grimes, 1978) \\
\hline Sources of identity & $\begin{array}{l}\text { The factors supporting the perception of belonging to a group of actors compared to another group (STETS and BURKE, 2000; } \\
\text { Ashforth and Mael, 1989) }\end{array}$ \\
\hline Basis of norms & $\begin{array}{l}\text { The factors underlying the shared expectations of individual and organizational actors that support accepted and sanctions } \\
\text { unwanted behavior }(0 \mathrm{pp}, 2001)\end{array}$ \\
\hline Basis of attention & $\begin{array}{l}\text { The factors initiating the top-down and bottom-up selection, sustenance and allocation of certain cognitive resources above others } \\
\text { (Ocasio, 1997, 2011) }\end{array}$ \\
\hline Basis of strategy & $\begin{array}{l}\text { The factors underlying the purposeful and emerging actions that create fit among an actor's activities (Porter, 1996; Ahlstrand } \\
\text { et al., 2001) }\end{array}$ \\
\hline $\begin{array}{l}\text { Informal control } \\
\text { mechanisms }\end{array}$ & The actors and factors that unobtrusively assist in supporting or correcting actor behavior (Goebel and Weißenberger, 2017) \\
\hline Economic system & $\begin{array}{l}\text { Goods- or service-centric economic reasoning, respectively, focusing on the exchange value or the use value of goods (Grönroos } \\
\text { and Voima, 2013; Gronroos and Gummerus, 2014; Vargo and Lusch, 2016) }\end{array}$ \\
\hline
\end{tabular}


use of the railway infrastructure for maintenance and train operation purposes. Despite this agreed-upon schedule, the perfect alignment of train operation, maintenance and construction activities at operational level is virtually impossible due to unexpected daily disturbances at operational level (e.g. failing infrastructure and trains, weather, third actors). The performance of the national train service, therefore, depends on whether the operational business units at regional level coordinate and integrate their resources to address these disturbances and form an EE. Hence, each of these regional railway settings forming a perfect research case in view of our research question.

\subsection{Method}

This paper uses a qualitative multiple case study approach because it enables to combine different data sources to capture the actions and experiences of actors, their collaboration and their used and emerging institutional logics. The three cases involved, Cases A, B and C are each responsible for the scheduled train service in either the national or a provincial concession. The differing train concession owners referred to as CIS (Cases A and B) and TRANS (Case C) offered the maximum variation and therefore determined the case selection (Flyvbjerg, 2006).

Each case consists of four core units, i.e. the asset and traffic management units of the RA and the traffic management and service and operations units of either CIS or TRANS. In addition, one or more preventive maintenance contractor units and a unit of the train maintenance firm (a CIS subsidiary) are involved. Case A consists of these units and, respectively, the maintenance contractors $\mathrm{B}$ and $\mathrm{D}$ units ( $\mathrm{MCb}$ and $\mathrm{MCd})$. In Case $\mathrm{B}$, in addition to the core units and the train maintenance unit, the performance analysis unit of the RA, the CIS EEsecretariat and local planning unit and the international train operator unit (a CIS subsidiary) are involved. Case C, though, has a different setup. Next to the core units, the train maintenance firm and $\mathrm{MCb}$ units, the planning and control unit of TRANS and the regional railway allocation unit of the $\mathrm{RA}$ are involved. In contrast to Cases $\mathrm{A}$ and $\mathrm{B}$, the service and operation manager of TRANS is a concession owner too.

The research followed the guidelines for research ethics. The research ensured that all interviewees and observed meetings agreed to participate and treated their information confidentially, not using it when so requested. Finally, the research did its utmost to prevent the identification of the EEs and interviewees.

\subsection{Data collection}

The data collection draws on three data sources: observations of EE meetings and inter- and intra-organizational meetings at strategic level, supported by semi-structured interviews, group conversations and archival materials. From July 2013 until February 2017, the observation of 40 meetings, execution of 31 semi-structured interviews and 9 feedback meetings took place (Table 3). Furthermore, reports and archival data (ranging from 2011-2017) were analyzed, which include concession documents, meeting minutes and internal presentations of the RA, CIS and TRANS.

The observation of series of meetings enabled the investigation of the used institutional logics and their effect on resource coordination and integration. In contrast to interviews, observations reveal the level of interactive contacts, the experienced and perceived organizational and interorganizational reality per business unit, and the ongoing negotiations about the sense-making and giving of this reality (Smets et al., 2012; Jerolmack and Khan, 2014; Weick et al., 2005; Gioia and Chittipeddi, 1991). From the start, the first author observed a number of railway allocation, asset management (AM) and project meetings at the RA office and gained access to inter-organizational meetings during the research. As a non-participating partner at the meeting tables, she observed the differing positions in the meetings and the opportunistic, defiant, submissive and collaborative behavior of the various actors involved. In addition, she listened to the shared, conflicting and neglected interpretations of their differing but related contractual and professional reasoning.

This research chose the semi-structured interview method to support the observation data. It did so because this method encourages interviewees to reflect and elaborate on meetings and the discussed ongoing concerns, which led to deeper insights into the observed behavior and their reasoning. On top of this, interviewees gave access to other meetings and valued resource persons, such as their colleagues, collaborating partners, senior managers and knowledgeable employees. This research thus snowballed its interviews and meetings. In the interviews, it asked the interviewees to describe their work and specify the contributions and challenges of their collaboration with the divisions and business units in their own and partner organization(s), as well as with contextual actors and to characterize the effect steering mechanisms had on the collaboration by giving examples of their own actions and experiences.

The feedback meetings resulting from research-related discussions and presentations validated the observational findings. Similarly, the archival data validated the observational and interview findings on the formal steering mechanisms and the intra- and inter-organizational management structure and processes.

Phase one of this intra- and inter-organizational research started in July 2013 and lasted until May 2014. This explorative phase gave first insights into the resource coordination and integration among the RA, its maintenance contractors, infrastructure projects, CIS and the freight train companies (Bobbink et al., 2014). Based on this, the research excluded the freight train operators, the RAs construction division, and their contractors and no longer focused on the financial and natural resources.

In phase two, which lasted from May 2014 to September 2015, Case A and dyadic AM contractor meetings were observed. In addition, various employees and managers of the business units involved, along with managers and employees of the concerned RA and CIS divisional managements were interviewed. Access to the $\mathrm{AM}$ - contractor meetings was sought because the contractor units did not take part in the EE meetings. However, access to these meetings was only gained in Case A.

In phase three, lasting from October 2015 to February 2017, a sequence of biweekly Case B and triweekly Case C meetings was observed, 18 in total. In addition, two supra-provincial meetings involving representatives of three provinces, the RA, CIS, TRANS and the train maintenance firm, and two national meetings involving the five CIS EEs were observed. Finally, five feedback meetings, one with Case B and Case C each, one with Case B's AM unit, who missed the feedback meeting, one for staff of the CIS national office and one with the EE secretaries of the five CIS EEs. 
Table 3 Primary data sources

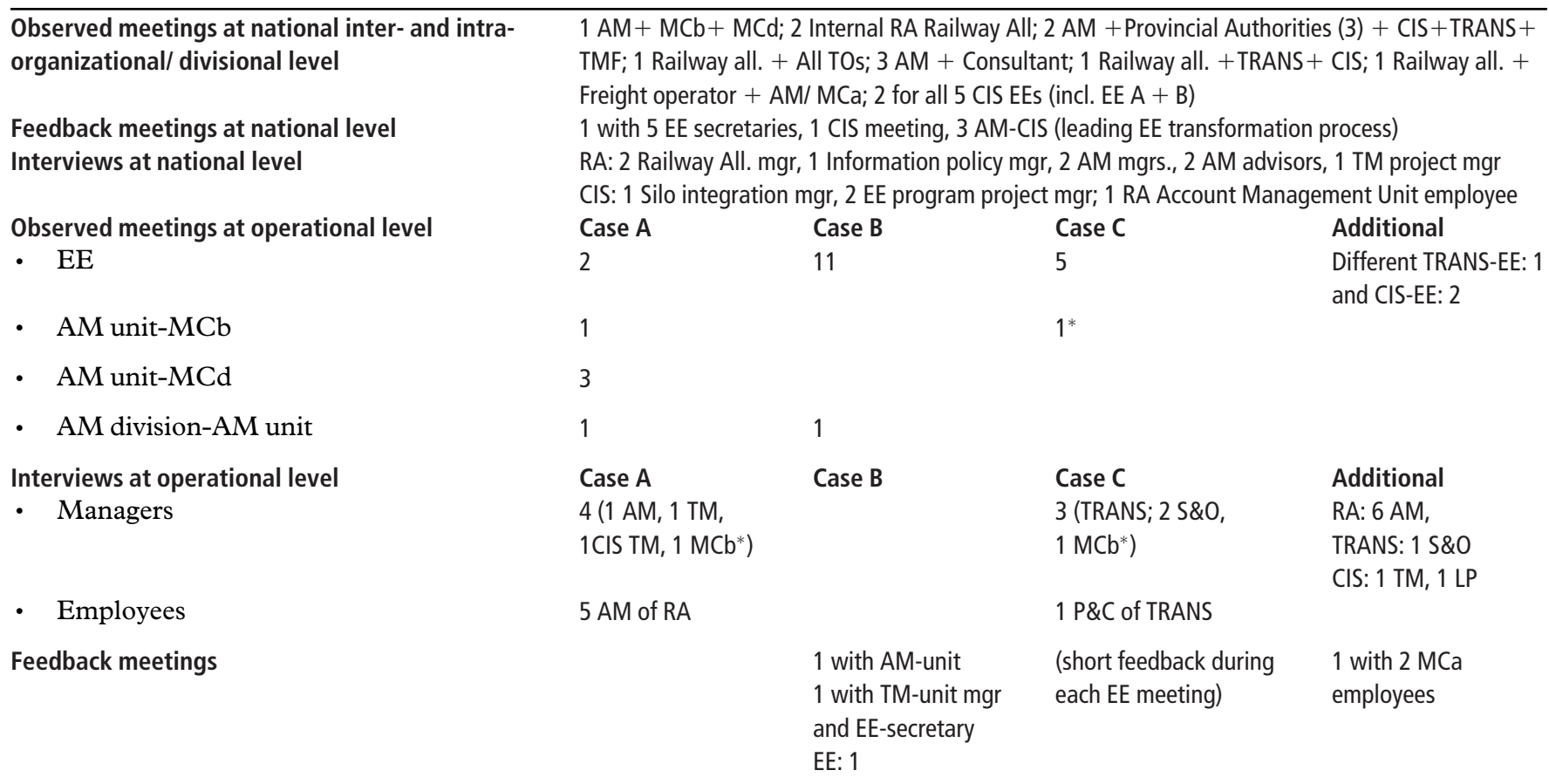

Notes: ${ }^{*}=$ same; $\mathrm{AM}=$ asset-management (division or unit) of the Railway agency (RA); Railway all. = Railway allocation division; TMF = train maintenance firm; TM = traffic management unit of the RA; $\mathrm{MCb}=$ maintenance contractor- $\mathrm{B} ; \mathrm{MCd}=$ maintenance contractor- $\mathrm{D} ; \mathrm{MCa}=$ maintenance contractor- $\mathrm{A}$; $\mathrm{S} \& 0=$ service and operations; $L P=$ local planning, $P \& C=$ planning and control

\subsection{Data analysis}

In line with qualitative research approaches, initially line-by-line coding of the transcribed interviews and meetings, and reports of interviews, meetings and group conversations took place. Iterative rounds of coding stressed the different perceptions and practices of the differing actors on how to sustain and improve the train service. During this process, it became evident that the appearing categories referred to differences in strategies, reasoning and practices of the business units, divisions, organizations and concession authorities involved. Reviewing performance management and measurement, supply chain management and EE literature did not shed enough light on these findings, but reading Edvardsson's (2014) article on the effect of institutional logics on resource integration did. The institutional logics and resource definitions used, though, were not exclusive enough, this in contrast to the categorical elements of the inter-institutional matrix proposed by Thornton et al. (2012). By defining and using these elements, three institutional logics were revealed, two of which are prevalent in both the hierarchical organizational context of and in the EEs, i.e. the performance and professional logics. The remaining one is a co-existing institutional logic at EE level, the cocreation logic. Subsequently, the effect of these logics on the social, intellectual, technical, legal and cultural resource coordination and integration of the three cases was established.

\section{Findings}

\subsection{Institutional logics at work}

The analysis revealed three institutional logics prevalent in the three cases: the performance, professional and co-creation logic (Table 4).

\subsubsection{The performance logic}

This logic uses concessions and contracts to control, manage, protect and where possible increase actor-owned technical and intellectual resources. In this manner, concession/contract authorities spread their risks over the concession/contract owners, often without necessarily taking care of their fair distribution. In the railway sector, for example, the RA's AM units are contractually responsible for weather and third-actor-related train incidents, thus reducing the risks and strengthening the negotiation position of the train operator units. A concessionarycreated juxtaposition that strengthens the employee perception of belonging to their own unit, while steering their attention only to their contractually determined technical resources. Staff introductions and training strengthen this attention, e.g. the training of traffic management employees on their own concessionary responsibilities. The same applies to the targets of concessionary and contract criteria because their positive target results strengthen the credibility and acceptance and with it the market position of actors, thus securing their presence and supporting the acquisition of new concessions/contracts. Hence, the performance logic grounds its economic system in legal resources, while attuning and improving its intellectual resources to it in support of its technical resources, leading to a resourcecentric economic system.

\subsubsection{The professional logic}

The professional logic improves and sustains the quality of professional expertise to reduce the risks of using product services. In the railway sector, its attention is on sustaining and improving the safety of the technical objects used, for example, 

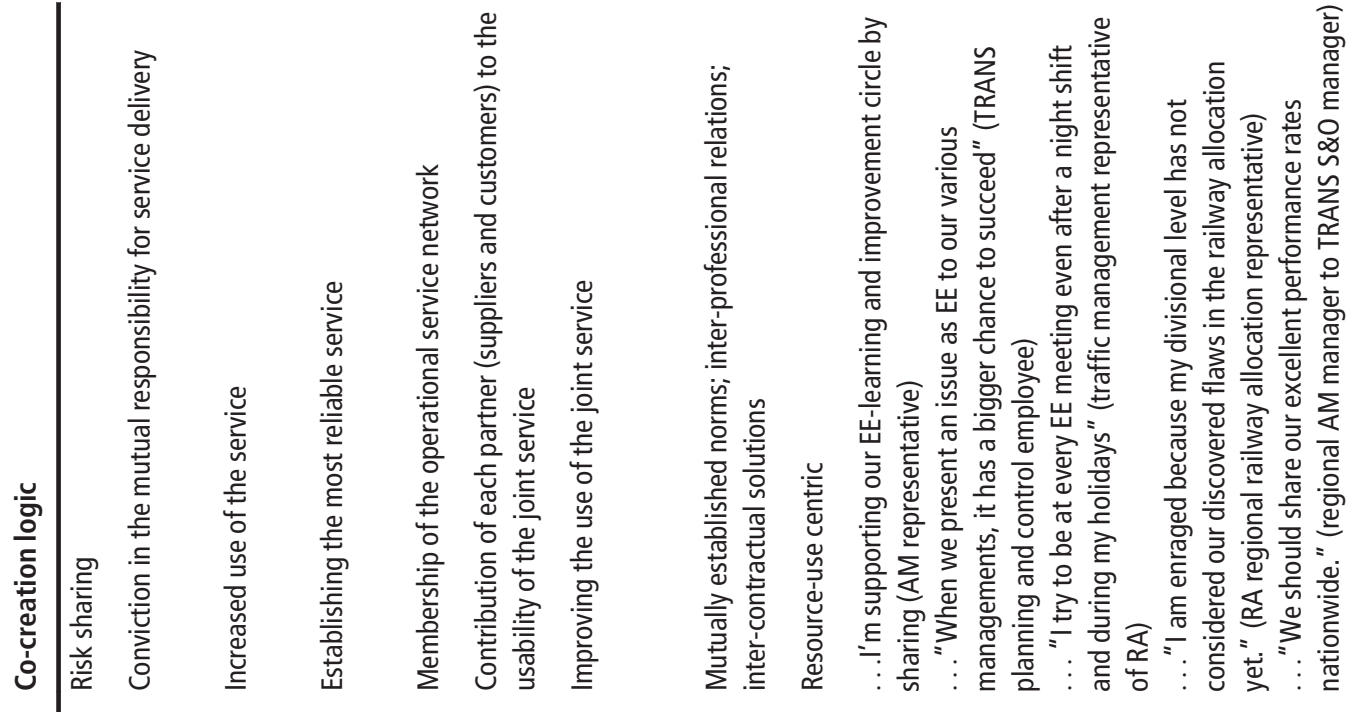

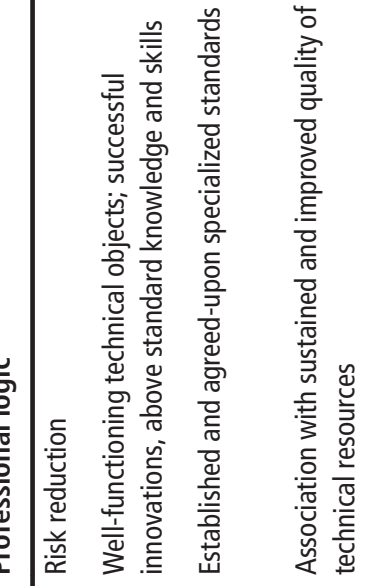
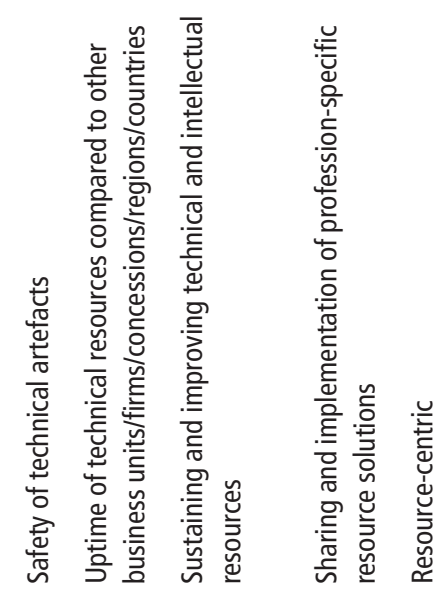

$$
\text { 宾离 }
$$

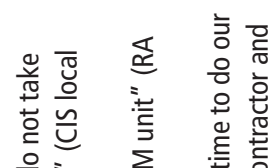

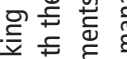

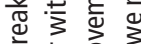

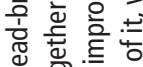

这

竞:

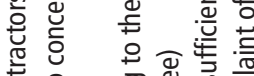

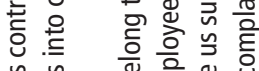

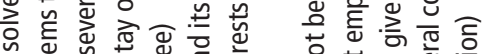

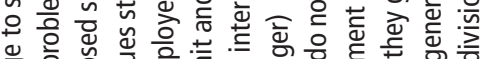

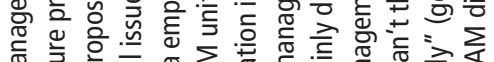

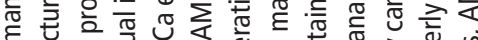

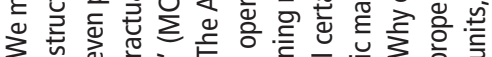

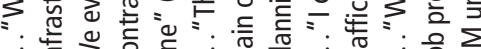

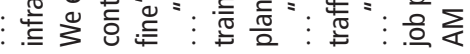

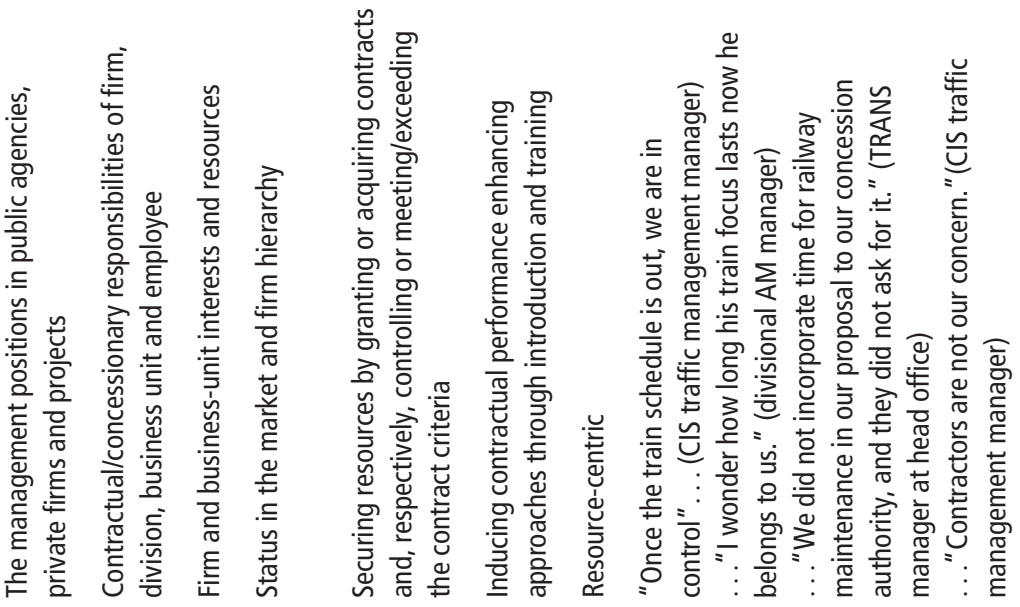

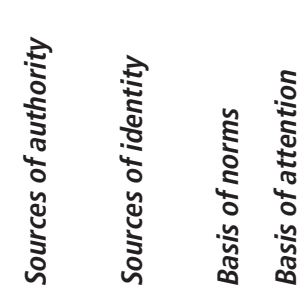

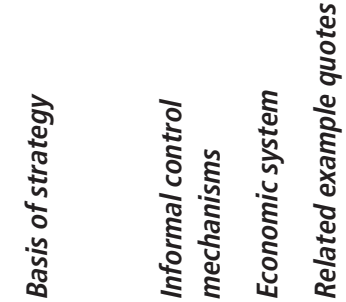<smiles>C1CC1C1CC1</smiles> 
the prevention of rapid train wheel and railway infra-wear by adapting train driving to slippery railways. Succeeding in this supports the acceptability and credibility of the professional expertise by peers and others.

Profession-specific norms embedded in legislation and captured in profession-specific standards assure the quality of the profession. In the railway sector, the railway law (Hagdorn, 2017) stipulates the standards for train operation and railway infrastructure maintenance, construction and allocation. The incorporation of these standards in separate contractual procedures aims to secure the safety of the technical artefacts and consequently the safety of their environment and of those using, maintaining and constructing these artefacts. Established professional standards that others recognize and adhere to aid in providing authority, e.g. a train guard's ability to fine passengers trying to embark after the departure whistle. Exceeding specific professional standards secures and focuses the attention of peers and others. This logic grounds its economic system on the available intellectual resources to support developing and sustaining its technical resources, also leading to a resource-centric economic system.

\subsubsection{The co-creation logic}

This logic establishes unity by sharing risks and improving both the resource use of the individual actors and the resource integration of all. To sustain this process, it seeks to accommodate the conflicting pointers of other logics, for example, the time needed for railway maintenance versus the time needed for train operation schedules. Hence, this logic supports attention to the use value of each other's contracts, expertise, experiences and work routines and the integration of this learning into a joint routine to improve the final service delivery. The resource-use-centric economic system of this logic results in performance improvements at the actor-specific and overall level, which increases the social acceptance and credibility of the actors using it. On top of this, this logic supports the creation of EE-supporting norms and regulations and the strengthening of inter-professional relations. Adhering to and nurturing these informal norms and regulations is a means to control the negative effect of the performance and professional logics in an EE and its organizational context, while this concurrently strengthens the co-creation logic.

\subsection{The effect of institutional logics on the resource coordination and integration in extended enterprises} In the three cases, the prevalent institutional logics had different effects on resource coordination and integration (Table 5).

\subsubsection{Case A: the effect of differing performance logics: lack of resource coordination and resource segregation}

In the Case A meetings, all participating units reasoned from their own divisional or organizational performance logic. A mutually recognized coordinator facilitating the integration of these logics was lacking. Hence, the participating units strengthened their contractual borders instead of exploring them. The only exception were the traffic management units of CIS and the RA because of a joint divisional project stressing their partly mirroring assignment. The resulting superficial personal relations, non-existent EE identity, reasoning on behalf of others, and disregard for the cornered and subordinate position of the AM unit, led to an overall resource segregation.

4.2.1.1 Social resources. Each operational unit focused on their own divisional or organizational assignment, which hindered building their EE. The shared identity and aligned agreements of both traffic management units and the AM-contractor units promoted the interpersonal relations among employees having partly mirroring assignments. The resulting dyad-centric behavior did not improve the interpersonal relations among these dyads and the other units, as a resource coordinator supporting their EE identity by mitigating their inter-unit and inter-dyad conflicts was lacking. Instead, they resolved conflicts and sought confirmation for resource integration actions via their contracting agency, division or organization.

4.2.1.2 Intellectual resources. The actor and dyad-centric behavior hindered the timely exchange and translation of information and mutual performance-sustaining or enhancing actions. Instead, units reasoned on behalf of other units, based on their own information gathering and/ or perceptions about these units. Hence, the information leading to mutual performance enhancing knowledge and actions was generally too little, too late. This led to an EE without executive power and units increasingly skipping the six-weekly EE meetings.

4.2.1.3 Technical resources. Case A specifically felt the effects of the mismatching of technical features of trains and railway infrastructure causing premature wear and tear because of their region's high traffic density and maintenance-ignoring railway construction. However, its units had no say in the choice of trains and railway infrastructure layout. Because of this, the AM and contractor units needed extra railway access time to re-address the effects of these mismatches, which was hard to get and spurred the railway access disputes with the CIS and the RA traffic management units.

The imposed performance measurement systems had a similar effect. Each unit focused on its own divisional/ organizational system; an EE system did not exist.

4.2.1.4 Legal resources. Due to the pilot improvement program on train service delivery initiated by the RA, CIS and their concession authority, consisting of divisional, bi-divisional and $\mathrm{EE}$ improvement projects, the RA and CIS traffic management divisions had started a bi-divisional process to align and harmonize their performance criteria at operational level in support of their concessionary key performance indicator (KPI), punctuality. This KPI supported their professional standards, too, thus strengthening their personal relations and shared identity, and hence increasing their rift with the other Case A units in particular because the EE project intending to bridge these differences had not started yet.

The main concessionary KPI of the AM unit, i.e. "train operation-affecting occurrences" (TAOs), consisted of five infrastructure disruption-causing criteria: infrastructure, climate, third actors, processes (RA, train operators, contractors) and "other." However, TAOs were not included in the contractor contracts. Their contractual criteria focused on infrastructure criteria only, such as the number of switches maintained and time needed to fix switch failures. Because of 
Table 5 The effect of the performance, professional and co-creation logic on the intended resource coordination and integration in three EEs in the railway sector

\begin{tabular}{|c|c|c|c|}
\hline Effect on & Performance Logic & Professional Logic & Co-creation logic \\
\hline $\begin{array}{l}\text { Resource } \\
\text { coordination }\end{array}$ & $\begin{array}{l}\text { Failing resource coordination because of } \\
\text { resource-centric interests }\end{array}$ & $\begin{array}{l}\text { Informal resource coordination among } \\
\text { professionally related, partly mirroring, } \\
\text { operational actors }\end{array}$ & $\begin{array}{l}\text { Informal resource coordination because of } \\
\text { recognition and integration of differing } \\
\text { performance and professional logics }\end{array}$ \\
\hline \multirow[t]{5}{*}{$\begin{array}{l}\text { Resource } \\
\text { integration }\end{array}$} & $\begin{array}{l}\text { Social resource segregation: } \\
\text { - Encourages function-specific } \\
\text { identity formation and } \\
\text { relationship building and } \\
\text { restrains relationship building } \\
\text { with differing functions and } \\
\text { professions }\end{array}$ & $\begin{array}{l}\text { Social resource segregation: } \\
\text { - Hinders relationships } \\
\text { between professionally differing } \\
\text { actors } \\
\text { - Legitimizes counterproductive } \\
\text { acting based on differing } \\
\text { professional identities }\end{array}$ & $\begin{array}{l}\text { Social resource integration: } \\
\text { - Encourages search for joint EE } \\
\text { identity } \\
\text { - Settles performance and } \\
\text { professional conflicts of interest } \\
\text { - Stresses and defends regular } \\
\text { personal contact }\end{array}$ \\
\hline & $\begin{array}{l}\text { Intellectual resource segregation: } \\
\text { - Encourages reasoning for other } \\
\text { actors } \\
\text { - Encourages hiding behind labor } \\
\text { contract } \\
\text { Technical resource segregation: } \\
\text { - Legitimizes using technical } \\
\text { resources for actor-specific } \\
\text { interests }\end{array}$ & $\begin{array}{l}\text { Intellectual resource segregation: } \\
\text { - Hinders exchange of differing } \\
\text { professional knowledge and skills } \\
\text { Technical resource segregation } \\
\text { - Hinders joint prioritizing of the } \\
\text { same technical resource, e.g. } \\
\text { use of railway infrastructure for } \\
\text { trains and maintenance } \\
\text { Legal resource segregation }\end{array}$ & $\begin{array}{l}\text { Intellectual resource integration: } \\
\text { - Erases borders between } \\
\text { conflicting performance and } \\
\text { professional logics } \\
\text { - Initiates exchange of knowledge } \\
\text { and asking for knowledge } \\
\text { support } \\
\text { Encourages the transfer and } \\
\text { translation of the differing } \\
\text { knowledge and skills of actors }\end{array}$ \\
\hline & $\begin{array}{l}\text { Legal resource segregation: } \\
\text { - Allows business actors to retreat } \\
\text { from EE } \\
\text { - Prevents EE resource integration } \\
\text { being part of actor management } \\
\text { contracts }\end{array}$ & $\begin{array}{l}\text { - Prevents informal } \\
\text { inter-professional agreements } \\
\text { Cultural resource segregation: } \\
\text { - Legitimizes prominent } \\
\text { position of "visible" } \\
\text { professions such as train }\end{array}$ & $\begin{array}{l}\text { Technical resource integration: } \\
\text { - Sharing use of technical } \\
\text { resources, such as allowing } \\
\text { barrier closing for speedy train } \\
\text { returns and securing train free } \\
\text { periods for maintenance }\end{array}$ \\
\hline & $\begin{array}{l}\text { Cultural resource segregation: } \\
\text { - Sustains and strengthens the } \\
\text { difference in position and } \\
\text { enhances "blaming" } \\
\text { - Supports imposing }\end{array}$ & $\begin{array}{l}\text { operation while downgrading } \\
\text { “invisible" professions, such as } \\
\text { railway maintenance }\end{array}$ & $\begin{array}{l}\text { Legal resource integration } \\
\text { - Supports reinterpreting and } \\
\text { bending of rules and regulations } \\
\text { for the benefit of the EE }\end{array}$ \\
\hline & $\begin{array}{l}\text { resource-centric interests } \\
\text { Allows for acceptance of } \\
\text { "invisible" actors, such as AM } \\
\text { unit, maintenance contractors } \\
\text { and train maintenance unit }\end{array}$ & & $\begin{array}{l}\text { Cultural resource integration: } \\
\text { - Counteracts on and resets firm- } \\
\text { centric strategic management } \\
\text { and profession-centric behavior } \\
\text { - Mutual norms for conflict } \\
\text { resolution and EE improvement } \\
\text { established and adhered to }\end{array}$ \\
\hline
\end{tabular}

their daily work on the railway tracks though, contractors possessed valuable information on the other TAO criteria, too. However, the AM unit could not contractually enforce the provision of this information. Hence, they connected to the contractor units by sharing their expertise, stressing their shared railway maintenance identity and pointing at those limiting their railway access, i.e. the traffic management and CIS units.

From the national perspective, a reduction in TAOs sustained an increase in punctuality, and thus the overall service delivery. At Case A level, this interdependency favored both traffic management and the service and operation units because they could blame a reduced punctuality on the $\mathrm{AM}$ and contractor units, without addressing the negative effect of their own practices:

[...]Driving with $130 \mathrm{~km} /$ hour past persons near to the track is frightening. Why should the CIS units care about your administrative performance at all? Your asset management performance is not their concern[...] (RA traffic manager in Case A meeting)

Efforts of the AM manager to create joint performance criteria at EE level supporting both concessionary KPIs failed because the CIS units stressed this was not their responsibility, but that of their divisional management.

4.2.1.5 Cultural resources The position of the different units in Case A differed due to the governmental and nationwide train-service focus, the neglected role of 
railway maintenance in this and the lacking and ignored knowledge about what railway maintenance entails. Because of this, the RA had tucked railway maintenance away into a nationwide, all-inclusive $4 \mathrm{~h}$ train-free timeslot (TFT) from 01.00-05.00 a.m.:

[...]I wonder what the directors of the Railway Sector and the Concession Authority talk about. I have a feeling it is about ever more trains, without attaching any importance to railway maintenance[...] (trajectory manager, asset management-unit)

In Case A, though, night trains, freight trains, infrastructure projects and the train maintenance firm made use of this same timeslot. Hence, the AM unit had to secure enough scheduled TFT on behalf of its contractor units during the annual railway allocation process, pointing to the necessity of maintenance activities. Once allotted, both had to defend their TFT especially when needing additional TFT to finish a maintenance job or repair an infrastructure disruption. Getting this additional TFT was virtually impossible because of the potential negative effect on the train schedules of their own and other operational regions, but at the same time, it was needed to prevent just that.

4.2.1.6 Summarized effect of the differing performance logics on Case $A$. The differing divisional and organizational performance logics are grounded in differing legal resources. The personifications (e.g. "our train and your AM performance") and representations of these resources (e.g. train and maintenance schedule, concessionary and contract KPIs) hindered not only the recognition of a mutually recognized resource coordinator but also their resource integration: a situation which resulted in the reasoning on behalf of other units; imposing resource-centric interests; retreating behind individual contracts and management agreements; sustaining and strengthening the existing differences in business-unit positions; allowing for skipping Case A meetings and the "invisibility" of concessionary/ contractually subordinate supplier units (AM, contractors and train maintenance units). This prevented the development of a Case A identity and the establishment of an informal resourceintegrating agreement. The hierarchically coordinated resource integration of the professional mirroring traffic management of RA and CIS and the AM units of RA and contractors, i.e. having similar professional-cum-performance logics, contributed to this resource segregation because of the increased focus on their own legal and intellectual resources.

\subsubsection{Case B: the effect of a dominant professional logic: resource-} integrating segregation

In the Case B meetings, seven of the nine participating units reasoned from a dominant professional logic grounded in trains and train operation. This professional logic strengthened the personal relations and shared identity in addition to improving their knowledge sharing about interrelated train schedules, train starts, train maintenance demands and fine-tuning their technical resources in support of it. However, the strengthening of this dominant professional logic ignored the identity, knowledge and technical resources of the AM unit and stressed the non-operational identity of the CIS local planning unit.
4.2.2.1 Social resources. In addition to participating in divisional improvement projects of the pilot RA-CIS improvement program, the units in the Case B meeting also participated in the EE project. The EE project's obligatory, full presence, biweekly meetings improved Case B's communication lines considerably:

[...] We know whom to contact now [...] and they know how to contact us $[\ldots]$ (asset management unit representative)

However, the divisional improvement trajectories and the train operation focus of the EE project hindered the creation of an EE identity and eventually drained Case B's resource-coordinating and integrating energy. The train operation units, for example, focused on improving the timely start and departure of trains and so did the visiting CIS directors, the overall EE project managing representatives and the consultant of the, Case B initiated, resource-integrating process. Because of it, they ignored the railway maintaining identity of the $\mathrm{AM}$ and contractor units, contributing to the informal withdrawal of the AM unit's representative from the Case B meeting:

[...] Our EE meeting only tackles CIS issues [...] (AM unit representative)

The train operation identity did not match the planning identity of the local planning unit either, which eventually contributed to their formal withdrawal from the Case B meeting. Although the coordinator and train operation units strongly disputed the withdrawal of the train operation-related local planning unit, they more or less accepted the withdrawal of the AM unit.

4.2.2.2 Intellectual resources. Supported by all units, the coordinator addressed the dissipating energy that the divisional improvement projects had caused in the Case B meeting. He initiated a consultancy process to improve the knowledge exchange on their differing work routines to improve train starts and strengthen the position of their EE in its hierarchical organizational context. The CIS-related consultant, though, failed to probe for the railway maintenance knowledge, while the AM unit failed to push for it and the train operation units hardly asked for it. Hence, Case B's train operation knowledge strengthened and ignored the railway maintenance involvement in improving their train service delivery.

This partial resource integration, though, improved Case B's position with respect to the divisional CIS management. For example, they added train parking and maintenance areas to their operational area, despite the instructions of a divisional CIS director stating that their responsibility stopped beyond their train station and shunting yard. However, they failed to include the operational area of the AM unit beyond it.

4.2.2.3 Technical resources. The increased demand for train services led to a steady increase of the number and length of trains. The available parking and maintenance areas for trains, though, did not increase. The train operation units had to bear the consequences of this mismatch:

[...] It is what you told me jokingly yesterday[...] "You don't have enough railway tracks for my trains"[...] I answered: No, you just have too many trains" [...] (TMF representative to TM representative (coordinator) in Case B meeting) 
In discussing their increasing problems because of the railway infrastructure shortage, the train operating units did not involve the AM unit, though it experienced similar problems. After all, the shortage of railway infrastructure reduced its railway access for maintenance while increasing the need for it. Incorporating these issues could have strengthened the Case B claim for additional railway infrastructure, instead of repeatedly being snubbed for it:

[...] Demanding additional railway infrastructure is not EE business [...] (CIS process facilitator-cum-lean consultant to Case B coordinator in first national EE meeting)

4.2.2.4 Legal resources. During the consultancy process, the Case B units had to add contributing, self-controlled, contractual performance criteria in support of their mutual objective. The assumption was that by monitoring, discussing and acting upon the results of these criteria, the effectiveness of their meetings would improve, the unitspecific and overall performance would increase, and the risks pertaining to their train service would be reduced. Discussing the criteria revealed the similarities and interrelations between the train operation units, but stressed the differences with the local planning and $A M$ units. In addition to the earlier mentioned social resource segregation process, this contributed to their withdrawal from the Case B meeting, too.

The subsequent reporting on these self-controlled criteria turned the attention to the unit-specific work routines but failed to address the overall workflow. This became apparent when discussing the targets of the concessionary KPI, punctuality. During these spare moments, they discussed the lacking management of their overall workflow, an issue the coordinator repeatedly mentioned to visiting CIS directors and in the national EE meetings, who replied that they should take up this management informally. Case B, though, failed to do so themselves.

4.2.2.5 Cultural resources. The positions of the train operation units leveled out because of the train focus of the pilot improvement program but failed to integrate the AM and local planning units. Two factors contributed to this: the earlier mentioned social, intellectual and legal integration of the train operation units only and the active CIS support to integrate the unit of the train maintenance firm. Where before the CIS and international train operator units could blame this unit for a late start or wrong coach setup, CIS had started to stress the need to provide the train maintenance unit with the proper information and the right carriage formation, thus changing this unit's previous scapegoat position. However, blaming the AM unit for written-off railway infrastructure and solving AM-related conflicts via their divisions/organizations continued:

[...] I keep on telling them (= train operation units) that replacing writtenoff railway infrastructure is the responsibility of the construction division, not ours[...] They simply do not want to understand, so what is the use of participating in the Case $\mathrm{B}$ meetings[...] (representative of asset management unit)

4.2.2.6 Summarized effect of the dominant professional logic on Case B. Case B's adjustment of an imposed train-starting strategy based on the resource representations of their own professional logics, e.g. the correct carriage formation, timely train arrival at the right platform, resulted in a dominant professional logic focused on train operation. This dominant professional logic enabled Case $\mathrm{B}$ to fend off the differing performance and professional logics of visiting divisional CIS directors. However, it hindered the social relations between the seven train-related units and the RA's AM (and its contractors) and the CIS local planning unit. Among them, it also hindered the exchange of professional knowledge and skills, the joint prioritizing of the same technical resources and the establishment of informal inter-professional agreements. Finally, it legitimized the prominent position of the "valued" train operation professions and ignored the position of the AM unit. Each of these exclusions hindered the formation of an EE identity and strengthened the resource-centric attention on either train operation, AM or local planning, resulting in a coordinated resource-integrating resource segregation.

\subsubsection{Case C: the effect of the co-creation logic, resource integration} The units involved in the Case $\mathrm{C}$ meeting reasoned each from their own performance and professional logics, but their additional co-creation logic, which the Case C coordinator unconsciously encouraged, interrelated their differing logics. The coordinator was able to do so because of his hierarchical overlapping position as TRANS concession owner. Also, being a recognized partner in the concession meeting enabled him to fend off the negative influences of his own organization and the $\mathrm{RA}$ on Case $\mathrm{C}$ and to ask for their support instead. Thus, he could protect Case C's co-existing co-creation logic, which stimulated reflection and allowed for the questioning and changing of existing knowledge, skills and power differences, strengthening the mutual understanding and social ties, which encouraged the search for and implementation of innovative Case C-level improvements. As a result, the various units forming Case $\mathrm{C}$ opened their contractual and professional borders and formed a strong EE.

4.2.3.1 Social resources. The coordinator's consistent mitigation of railway access conflicts between the stand-alone AM unit and the train operation units supported the Case C meeting efforts for joint improvements and resulted in strong personal relations and a shared Case C identity. Because of this, not only the railway infrastructure improved but also its use by TRANS and the RA's traffic management unit. The latter, for example, adapted the nationally agreed railway allocation to TRANS's needs:

[...] We are doing so well because we trust each other[...] (traffic management representative in Case $\mathrm{C}$ meeting)

The train maintenance unit did not take part in the Case C meetings and neither did the $\mathrm{MCb}$ unit. The train maintenance unit was not part of the Case C identity. When discussing train maintenance issues, the disinterest of the train maintenance unit in TRANS trains and its tightening bond with CIS were stressed:

[...] CIS is increasingly re-integrating the train maintenance firm[...] (Coordinator in Case C meeting)

The $\mathrm{MCb}$ unit, though, was unknowingly part of the Case C identity because of its dyadic relation with the AM unit.

4.2.3.2 Intellectual resources. Led by their coordinator, the units shared their expertise and experiences willingly. They articulated what was on their mind, added to or corrected arguments based on information gathering, asked explanatory questions, gave out-of-the box suggestions and sought for mutual understanding, which aided solving or finding the underlying reasons for their encountered problems, for example, on the delayed start of train operation because of a frozen-over catenary 
system. The result was a new protocol launching three locomotives at the start of train operation during glazed frost periods from the winter of 2016-2017 onwards.

They also uncovered strategic capacity-planning flaws of the RA hindering their mutual performance, which they repeatedly addressed in vain to the divisional railway allocation level: for example, the RA's reassignment of their not-used railway access time by construction projects to freight trains instead; using unrealistic construction project planning schedules in the railway allocation planning leading to foreseeable train operation disruptions; freight trains hindering their train schedule. However, at their own level not including the train maintenance unit in this process led, among others, to hiring the wrong mechanics for the planned revisions of TRANS trains, while not including the $\mathrm{MCb}$ unit prevented the discussion on alternate railway maintenance periods.

4.2.3.3 Technical resources. The railway infrastructure construction of a bypass had solved a large part of the infrastructure problems of TRANS, enabling a partly 15-min train schedule on their mainly single railway track. Because of the location of this track and the scarce alternates for railway tracks under construction, part of the routing and rerouting of freight trains took place on it, which had a negative bearing on the TRANS train schedule.

At their own level, Case C improved the integrated use of their technical artefacts as much as possible. For example, they effectively used the closing of railway crossing barriers and train personnel planning for allowing short train returns; maintained and repaired the railway as much as possible during the TFT at night and during construction projects; instructed specific train driving during autumn, reducing the wear and tear of railway infrastructure and trains - all of which contributed to an improved train service delivery.

4.2.3.4 Legal resources. All units in the Case C meeting focused on improving the target of TRANS concessionary KPI, punctuality and limiting its train-cancellations. Because its unit representatives were willing to cross their contractual boundaries, legal resource integration became possible, though informally. The RA's traffic management unit, for example, adjusted the annually agreed railway allocation to the train operation needs of TRANS:

[...]My staff wrongfully thinks that this is the nationally agreed train allocation [...] (Representative RA's traffic management unit in Case C meeting)

The resulting excellent punctuality performance (99\%) supported the RA's punctuality and TAO targets.

In turn, the coordinator, being TRANS S\&O manager and concession owner, assured a smooth train operation through his personnel instructions and planning. The "autumn driving instructions" for slippery railway tracks reduced related train cancellations and prevented blaming the AM unit for it. The only downside was the limited maintenance time: a $2.5 \mathrm{~h}$ TFT combined with a monthly $5.5 \mathrm{~h}$ TFT, instead of the standard $4 \mathrm{~h}$ TFT from 01:00 to 05:00 a.m. Despite the fact that the joint risk-sharing focus of the Case C meeting supported looking for and applying innovative alternates to ensure this limited time, this did not solve the contractor's nightmare of deploying and retaining personnel because of these TFTs.
4.2.3.5 Cultural resources. The Case $\mathrm{C}$ meeting units shared the same position because of their shared norms of not jumping to conclusions, but listening to and respecting each other:

[...]We do not copy the accusing behavior of our firm's traffic management office. This is simply not how we agreed to approach each other" [...] (coordinator Case C meeting)

These norms did not yet count for the $\mathrm{MCb}$ unit, though its manager expressed interest in having direct communication lines with TRANS to discuss and negotiate railway access needs and possibilities to avoid miscommunications. The coordinator supported this reasoning. However, for the traffic management representative, inviting the contractor unit to their meeting was one bridge too far because of his performance logic:

[...] The recent consultant report evaluating the major train cancellation in our RA region (Case A plus Case C) specifically stated we should keep to our designated roles, so my contact is the AM unit, and certainly not the contractor[...] (traffic management representative, Case C meeting)

The widely commended excellent performance of Case C could not prevent the withdrawal of unit representatives and units because their divisional and organizational management teams did not formally recognize their meeting, coordinator and mandate. Hence, the AM unit participated once every other meeting and the TRANS head office pulled out its planning and coordination unit. However, the latter's representative did not follow this order because of the learning and innovation opportunities in Case C.

4.2.3.6 Summarized effect of the co-creation logic in Case $C$. The six units in the Case $\mathrm{C}$ meetings reasoned each from their own performance and professional logics. Their additional cocreation logic interrelated the resource personifications and representations of their differing logics. This enabled not only the strengthening of their joint EE identity and social relations but also the sharing of their knowledge, skills and technical resources and the re-interpretation of their resourcesegregating contractual rules. The latter, in turn, supported the establishment of informal agreements and mutual norms to safeguard their EE effort. The hierarchical overlapping position of especially their coordinator-cum-concession owner supported the co-creation logic. Because of this overlapping position, they could fend off the interference of the divisional and organizational performance logics and form a strong EE focused on sustaining its resource coordination and integration.

\section{Discussion}

A remaining challenge of supply chain clusters such as EEs is the resource integration and coordination of the involved business units for the overall product-service delivery. By adopting an institutional logic perspective this paper offers new insights into this challenge. It, first of all, shows that EEs belonging to the same hierarchical supply chain can have different co-existing resource-integrating and resourcesegregating logics. Additionally, it reveals that each logic's categorical elements are grounded in varying combinations of resources and that these combinations determine a logic's resource-integrating or segregating character.

The multiple case study of the Dutch railway sector revealed three institutional logics: the performance logic primarily grounded in legal resources, the professional logic in 
intellectual and technical resources and the co-creation logic in social and intellectual resources. The personifications and representations of these resources strengthen the logics' grounding (Bourdieu, 1986; Misangyi et al., 2008; Ngoye et al., 2019) and appear to be critical for the resource coordination and integration in supply chains. The resource personifications and representations of the performance logic (e.g. management position and contracts) and the professional logic (e.g. maintenance expert and maintenance-norms) show a strong resource-centric tendency that segregates rather than integrates the resources of an EE's business units. These logics seem persistent and hard to change especially because of the continued use of their resource representations (e.g. railway schedules, contractual KPIs). The co-creation logic is able to alleviate the segregation effect of these logics by interlinking them and allowing the joint translation and transformation of the resource-centric personifications and representations. This suggests that the agency needed for resource coordination and integration builds on an interlinking co-creation logic and if such logic is absent business units sharing similar resource personifications and/or representations are prone to mimic each other (Reusen et al., 2020) forming dyadic and multi-tier inter-organizational factions. This, in turn, hinders the resource coordination and integration in EEs (Flynn et al., 2010).

This paper's findings support that intra- and inter-organizational commitment at the hierarchical and EE-level of supply chains is critical for their resource coordination and integration (Fawcett et al., 2006; Reusen et al., 2020). They also suggest that the resource-centrism of a supply chain's institutional logics results in paying lip-service to integration efforts. Hence, the commitment, relationships, capabilities and technologies meant to support supply chain integration (Flynn et al., 2010; Yu and Huo, 2018; Rajaguru and Matanda Margaret, 2019; Reusen et al., 2020) appear to depend on an interlinking co-creation logic.

Previous research revealed that the dominance and constellation of institutional logics determine organizational and interorganizational design (Besharov and Smith, 2014; Annala et al., 2019). However, proper leadership appears to be essential too (Kampstra et al., 2006). Our findings support both. The dominance and constellation of logics determined the organizational design of the three cases, and so did the presence and institutional logic of the focal resource coordinator. In Case A, the absence of the latter, resulted in a disintegrated $\mathrm{EE}$ consisting of separate silos and one, hierarchically induced, dyadic faction. The professional logic of the Case B coordinator and six train-related units excluded the AM and contractor-units, resulting in a factional train-operation cluster. In Case C, the coordinator's co-creation logic connected the differing resource personifications and representations of the EE's business units (including his own), which supported their mutual learning resulting in improved $\mathrm{EE}$ business unit and firm performances.

In addition, the hierarchically overlapping organizational positions of the Case $\mathrm{C}$ coordinator and two business unit representatives enabled the emergence of the co-creation logic, which supported Case $\mathrm{C}$ in averting resource-centric hierarchical supply chain interferences. Cases A and B not having similar positions were virtually unable to do so, hindering their resource integrating initiatives. Boundaryspanning positions (Williams, 2002; Smink et al., 2015) thus seem crucial for EEs because the mandates of these positions protect the emergence of a co-creation logic against the dominance of resource-centric logics.

\subsection{Limitations and directions for future research}

This paper underrepresents certain organizations/units that also played a role in the resource coordination and integration of the researched EEs, for example, the maintenance contractors, train maintenance firm, construction project contractors, freight operators and their shipping agencies. However, the observations of RA, EE and national meetings and interviews with $A M$, contractor and CIS and TRANS representatives provided some insights. Research into the perspective of the private freight train actors therefore could provide a stronger foundation for the revealed institutional logics and their effect on freight train EEs and freight-cum-passenger-train EEs.

A second limitation is that this paper did not research the effect of the institutional logics on the coordination and integration of the EEs' natural and financial resources. They undoubtedly have a bearing on them. It could be of interest to research this effect in EEs involved in railway infrastructure expansion. Another interesting research topic would be to reveal the effect of institutional logics on the financial consequences of using each other's resources.

Finally, the generalization of the findings of this explorative research focused on three cases of a specific sector in one country is limited. Expanding it to neighboring countries or examining the effect of institutional logics on other EE-settings could provide a stronger foundation for the found effect of resource-centric logics and the interlinking logic focusing on the use of their resource personifications and representations on the resource coordination and integration in EEs and supply chains in general to improve and sustain them.

\section{Conclusions}

Institutional logics appear to matter for sustaining EEs because in the research-context of this paper the resource-centric logics governing EEs and their hierarchical supply chain context not only resulted in failing resource coordination but also in resource segregation. A co-existing interlinking logic mitigating the personifications and representations of the differing, resource-centric, institutional logics appears to support the resource coordination and integration in EEs. Becoming aware of the institutional logics present in an EE and its supply chain/ network context, their resource personifications and representations, and addressing the latter for the benefit of the $\mathrm{EE}$ are essential skills for both the EE management and contractual/concessional authorities.

\section{References}

Ahlstrand, B., Lampel, J. and Mintzberg, H. (2001), Strategy Safari: A Guided Tour through the Wilds of Strategic Management, Simon and Schuster.

Annala, L., Polsa, P.E. and Kovács, G. (2019), "Changing institutional logics and implications for supply chains: Ethiopian rural water supply", Supply Chain Management: An International fournal, Vol. 24 No. 3, pp. 355-376.

Arshinder, K.A. and Deshmukh, S.G. (2008), "Supply chain coordination: perspectives, empirical studies and research 
directions", International fournal of Production Economics, Vol. 115, pp. 316-335.

Ashforth, B.E. and Mael, F. (1989), "Social identity theory and the organization", Academy of Management Review, Vol. 14 No. 1, pp. 20-39.

Barnard, C.I. (1968), The Functions of the Executive, Harvard University Press.

Barratt, M. (2004), "Understanding the meaning of collaboration in the supply chain", Supply Chain Management: An International foumal, Vol. 9 No. 1, pp. 30-42.

Besharov, M.L. and Smith, W.K. (2014), "Multiple institutional logics in organizations: explaining their varied nature and implications", Academy of Management Review, Vol. 39 No. 3, pp. 364-381.

Bititci, U., Garengo, P., Dörfler, V. and Nudurupati, S. (2012), "Performance measurement: challenges for tomorrow", International fournal of Management Reviews, Vol. 14 No. 3, pp. 305-327.

Bititci, U.S., Mendibil, K., Martinez, V. and Albores, P. (2005), "Measuring and managing performance in extended enterprises", International fournal of Operations \& Production Management, Vol. 25 No. 4, pp. 333-353.

Bobbink, M.L., Hartmann, A. and Degenhart, R. (2014), "Rail-infrastructure performance: the conflict between railavailability for maintenance and operation", Civil-Comp Proceedings, Civil-Comp Press, p. 104.

Bobbink, M., Hartmann, A. and Dewulf, G. (2016), "Sustaining extended enterprise performance: a value co-creation perspective", fournal of Organization Design, Vol. 5 No. 1, p. 3.

Bourdieu, P. (1986), "The forms of capital", in Richardson, J. (Ed.) Handbook of Theory and Research for the Sociology of Education, Greenwood, West Port, CT.

Bourdieu, P. (2005), The Social Structures of the Economy, Polity Press, Cambridge.

Braziotis, C. and Tannock, J. (2011), "Building the extended enterprise: key collaboration factors", The International Fournal of Logistics Management, Vol. 22 No. 3, pp. 349-372.

Cloutier, C. and Langley, A. (2013), "The logic of institutional logics: insights from French pragmatist sociology", fournal of Management Inquiry, Vol. 22 No. 4, pp. 360-380.

Cox, A. (1999), "Power, value and supply chain management", Supply Chain Management: an International foumal, Vol. 4, pp. 167-175.

Dimaggio, P.J. and Powell, W.W. (1983), "The iron cage revisited: institutional isomorphism and collective rationality in organizational fields", American Sociological Review, Vol. 48 No. 2, pp. 147-160.

Edvardsson, B., Kleinaltenkamp, M., Tronvoll, B., Mchugh, P. and Windahl, C. (2014), "Institutional logics matter when coordinating resource integration", Marketing Theory, Vol. 14 No. 3, pp. 291-309.

Fawcett, S.E. and Magnan, G.M. (2002), "The rhetoric and reality of supply chain integration", International fournal of Physical Distribution \& Logistics Management, Vol. 32 No. 5, pp. 339-361.

Fawcett, S.E., Mccarter, M.W., Fawcett, A.M., Webb, G.S. and Magnan, G.M. (2015), "Why supply chain collaboration fails: the socio-structural view of resistance to relational strategies", Supply Chain Management: An International fournal, Vol. 20 No. 6, pp. 648-663.
Fawcett, S.E., Ogden, J.A., Magnan, G.M. and Cooper, M.B. (2006), "Organizational commitment and governance for supply chain success", International fournal of Physical Distribution E Logistics Management, Vol. 36 No. 1, pp. 22-35.

Flynn, B.B., Huo, B. and Zhao, X. (2010), "The impact of supply chain integration on performance: a contingency and configuration approach", Fournal of Operations Management, Vol. 28, pp. 58-71.

Flyvbjerg, B. (2006), "Five misunderstandings about casestudy research", Qualitative Inquiry, Vol. 12, pp. 219-245.

Folan, P. and Browne, J. (2005), "Development of an extended enterprise performance measurement system", Production Planning \& Control, Vol. 16, pp. 531-544.

Friedland, R. and Alford, R.R. (1991), "Bringing society back in: symbols, practices and institutional contradictions", pp. 232-263.

Gioia, D.A. and Chittipeddi, K. (1991), "Sensemaking and sensegiving in strategic change initiation", Strategic Management fournal, Vol. 12 No. 6, pp. 433-448.

Gligor, D., Bozkurt, S., Russo, I. and Omar, A. (2019), “A look into the past and future: theories within supply chain management, marketing and management", Supply Chain Management: An International foumal, Vol. 24 No. 1, pp. 170-186.

Goebel, S. and Weißenberger, B.E. (2017), "Effects of management control mechanisms: towards a more comprehensive analysis", Fournal of Business Economics, Vol. 87 No. 2, pp. $185-219$.

Goldstein, B. and Newell, J.P. (2019), "Why academics should study the supply chains of individual corporations", fournal of Industrial Ecology, Vol. 23 No. 6, pp. 1316-1327.

Grimes, A.J. (1978), "Authority, power, influence and social control: a theoretical synthesis", Academy of Management Review, Vol. 3 No. 4, pp. 724-735.

Gronroos, C. and Gummerus, J. (2014), "The service revolution and its marketing implications: service logic vs service-dominant logic”, Managing Service Quality, Vol. 24, pp. 206-229.

Grönroos, C. and Voima, P. (2013), "Critical service logic: making sense of value creation and co-creation", fournal of the Academy of Marketing Science, Vol. 41 No. 2, pp. 133-150.

Gulati, R., Puranam, P. and Tushman, M. (2012), "Metaorganization design: rethinking design in interorganizational and community contexts", Strategic Management fournal, Vol. 33 No. 6, pp. 571-586.

Hagdorn, A., Sütö, V. and Wedzinga, A. (2017), Handboek Spoorwegrecht, Uitgeverij Paris bv, Zutphen.

Heather, S., Janet, G., Yew, W.C., Soroosh, S. and Denyse, J. (2015), "Supply chain alignment for improved business performance: an empirical study", Supply Chain Management: An International fournal, Vol. 20, pp. 511-533.

Jerolmack, C. and Khan, S. (2014), "Talk is cheap ethnography and the attitudinal fallacy", Sociological Methods E Research, Vol. 43, pp. 178-209.

Kähkönen, A.K. (2014), "The influence of power position on the depth of collaboration", Supply Chain Management: An International fournal, Vol. 19 No. 1, pp. 17-30.

Kampstra, R.P., Ashayeri, J. and Gattorna, J.L. (2006), "Realities of supply chain collaboration", The International Fournal of Logistics Management, Vol. 17, pp. 312-330.

Kauppi, K. (2013), "Extending the use of institutional theory in operations and supply chain management research: review 
and research suggestions", International fournal of Operations E Production Management, Vol. 33 No. 10, pp. 1318-1345.

Kauppi, K. and Hannibal, C. (2017), "Institutional pressures and sustainability assessment in supply chains", Supply Chain Management: An International fournal, Vol. 22 No. 5.

Laud, R., Arevalo, J. and Johnson, M. (2015), “The changing nature of managerial skills, mindsets and roles: advancing theory and relevancy for contemporary managers", fournal of Management $\mathcal{E}$ Organization, Vol. 22 No. 4, pp. 435-456.

Lehtinen, J. and Ahola, T. (2010), "Is performance measurement suitable for an extended enterprise?", International fournal of Operations \& Production Management, Vol. 30 No. 2, pp. 181-204.

Lemke, F., Clark, M. and Wilson, H. (2011), "Customer experience quality: an exploration in business and consumer contexts using repertory grid technique", Fournal of the Academy of Marketing Science, Vol. 39 No. 6, pp. 846-869.

Leuschner, R., Rogers, D.S. and Charvet, F.F. (2013), "A metaanalysis of supply chain integration and firm performance", Fournal of Supply Chain Management, Vol. 49 No. 2, pp. 34-57.

Masten, K.A. and Kim, S.L. (2015), "So many mechanisms, so little action: the case for 3rd party supply chain coordination", International fournal of Production Economics, Vol. 168, pp. 13-20.

Misangyi, V.F., Weaver, G.R. and Elms, H. (2008), "Ending corruption: the interplay among institutional logics, resources, and institutional entrepreneurs", Academy of Management Review, Vol. 33 No. 3, pp. 750-770.

Morgan, G. (1983), "More on metaphor: why we cannot control tropes in administrative science", Administrative Science Quarterly, Vol. 28 No. 4, pp. 601-607.

Ngoye, B., Sierra, V. and Ysa, T. (2019), "Different shades of gray: a priming experimental study on how institutional logics influence organizational actor judgment", Public Administration Review, Vol. 79 No. 2, pp. 256-266.

Ocasio, W. (1997), "Towards an attention-based view of the firm", Strategic Management fournal, Vol. 18, pp. 187-206.

Ocasio, W. (2011), “Attention to attention", Organization Science, Vol. 22 No. 5, pp. 1286-1296.

Ocasio, W. and Gai, S.L. (2020), "Institutions: everywhere but not everything”, Fournal of Management Inquiry, Vol. 29 No. 3, p. 1056492619899331.

O'Neill, H. and Sackett, P. (1994), "The extended manufacturing enterprise paradigm", Management Decision, Vol. 32, pp. 42-49.

Opp, K.-D. (2001), "How do norms emerge? An outline of a theory", Mind E Society, Vol. 2, pp. 101-128.

Osborne, S.P., Radnor, Z. and Nasi, G. (2013), “A new theory for public service management? Toward a (public) servicedominant approach", The American Review of Public Administration, Vol. 43 No. 2, pp. 135-158.

Pache, A.C. (2010), "The art of managing conflicting institutional logics: the case of social integration enterprises", Academy of Management 2010 Annual Meeting - Dare to Care: Passion and Compassion in Management Practice and Research, AOM.

Paulin, M. and Ferguson, R.J. (2010), "Relational norms in interfirm exchanges: from transactional cost economics to the service-dominant logic", Fournal of Business-to-Business Marketing, Vol. 17 No. 4, pp. 365-405.
Porter, M.E. (1996), "What is strategy", in Henry Mintzberg, E. A. (Ed.), The Strategy Process; Concepts, Concepts, Cases, 2nd European published 2003 ed., Pearson Education, Harlow.

Post, J.E., Preston, L.E. and Sachs, S. (2002), "Managing the extended enterprise: the new stakeholder view", California Management Review, Vol. 45 No. 1, pp. 6-28.

Power, D. (2005), "Supply chain management integration and implementation: a literature review", Supply Chain Management: An International fournal, Vol. 10 No. 4, pp. 252-263.

Rajaguru, R. and Matanda Margaret, J. (2019), "Role of compatibility and supply chain process integration in facilitating supply chain capabilities and organizational performance", Supply Chain Management: An International fournal, Vol. 24, pp. 301-316.

Reusen, E., Stouthuysen, K., Roodhooft, F., VAN DEN Abbeele, A. and Slabbinck, H. (2020), "Imitation of management practices in supply networks: relational and environmental effects", fournal of Supply Chain Management, Vol. 56 No. 1, pp. 54-72.

Scott, W.R. (2012), “The institutional environment of global project organizations”, Engineering Project Organization fournal, Vol. 2, pp. 27-35.

Scott, W.R. (2013), Institutions and Organizations: Ideas, Interests, and Identities, E-book ed., Sage Publications.

Seepma, A.P., DE Blok, C. and VAN Donk, D.P. (2020), "Designing digital public service supply chains: four countrybased cases in criminal justice", Supply Chain Management.

Shaw, J.A., Kontos, P., Martin, W. and Victor, C. (2017), "The institutional logic of integrated care: an ethnography of patient transitions", fournal of Health Organization and Management, Vol. 31 No. 1, pp. 82-95.

Smets, M., Morris, T. and Greenwood, R. (2012), "From practice to field: a multilevel model of practice-driven institutional change", Academy of Management fournal, Vol. 55 No. 4, pp. 877-904.

Smink, M., Negro, S.O., Niesten, E. and Hekkert, M.P. (2015), "How mismatching institutional logics hinder niche-regime interaction and how boundary spanners intervene", Technological Forecasting and Social Change, Vol. 100, pp. 225-237.

Spekman, R. and Davis, E.W. (2016), "The extended enterprise: a decade later", International fournal of Physical Distribution \& Logistics Management, Vol. 46 No. 1, pp. 43-61.

Spencer, M.E. (1970), "Weber on legitimate norms and authority", The British fournal of Sociology, Vol. 21 No. 2, pp. 123-134.

Stets, J.E. and Burke, P.J. (2000), "Identity theory and social identity theory", Social Psychology Quarterly, Vol. 63 No. 3, pp. 224-237.

Stevens, G.C. and Johnson, M. (2016), "Integrating the supply chain ... 25 years on", International fournal of Physical Distribution E Logistics Management, Vol. 46, pp. 19-42.

Thornton, P.H., Ocasio, W. and Lounsbury, M. (2012), The Institutional Logics Perspective: A New Approach to Culture, Structure, and Process, Oxford University Press on Demand.

Vargo, S.L. and Lusch, R.F. (2016), "Institutions and axioms: an extension and update of service-dominant logic", fournal of the Academy of Marketing Science, Vol. 44 No. 1, pp. 5-23.

Verdecho, M.J., Alfaro-Saiz, J.J. and Rodriguez-Rodriguez, R. (2012), "Prioritization and management of inter-enterprise collaborative performance", Decision Support Systems, Vol. 53 No. 1, pp. 142-153. 
Wang, S., Li, J., Song, J., Li, Y. and Sherk, M. (2018), "Institutional pressures and product modularity: do supply chain coordination and functional coordination matter?", International Fournal of Production Research, Vol. 56 No. 20, pp. 6644-6657.

Weick, K.E., Sutcliffe, K.M. and Obstfeld, D. (2005), "Organizing and the process of sensemaking", Organization Science, Vol. 16 No. 4, pp. 409-421.

Williams, P. (2002), "The competent boundary spanner", Public Administration, Vol. 80 No. 1, pp. 103-124.
Yu, Y. and Huo, B. (2018), "Supply chain quality integration: relational antecedents and operational consequences. Supply chain management", An International fournal, Vol. 23, pp. 188-206.

\section{Corresponding author}

Maria Lammerdina Bobbink can be contacted at: m.l. bobbink@utwente.nl

For instructions on how to order reprints of this article, please visit our website:

www.emeraldgrouppublishing.com/licensing/reprints.htm

Or contact us for further details: permissions@emeraldinsight.com 